\title{
POSTRZEGANIE OSÓB Z NIEPEŁNOSPRAWNOŚCIĄ PRZEZ UCZNIÓW SZKOŁY PODSTAWOWEJ. PRZEMIANY W REZULTACIE ODDZIAŁYWAŃ EDUKACYJNYCH
}

\begin{abstract}
Streszczenie: Przygotowanie środowiska włączającego, tj. środowiska, które sprzyja rozwojowi osób z niepełnosprawnością, staje się ważnym wyzwaniem dla współczesnej szkoły. Jednym z zadań zmierzających do urzeczywistniania tej idei jest przełamywanie stereotypów dotyczących osób z niepełnosprawnością i kształtowanie odpowiedniego wobec nich stosunku. Podjęte badania empiryczne miały na celu diagnozę postaw wobec osób z różnymi rodzajami niepełnosprawności prezentowanych przez uczniów ogólnodostępnej szkoły podstawowej, a także określenie ich zmian w kontekście oddziaływań edukacyjnych. Uzyskane wyniki pokazują, że odpowiednio zaplanowane i przeprowadzone oddziaływania edukacyjne przybliżające uczniom różnorodne aspekty funkcjonowania osób niepełnosprawnych przyczyniają się do zmiany ich postaw.
\end{abstract}

Słowa kluczowe: postawy wobec osób z niepełnosprawnością, zmiany postaw, inkluzja społeczna, oddziaływania edukacyjne

\section{WPROWADZENIE}

Wielość obserwowanych w ostatnich latach akcji społecznych i medialnych mających na celu przybliżenie zagadnień związanych z funkcjonowaniem osób z niepełnosprawnością skłania do podjęcia analiz ich wpływu na realne postawy społeczne. Zagadnienie to staje się szczególnie ważne w kontekście stojących przed edukacją ogólnodostępną wyzwań związanych z inkluzją uczniów z niepełnosprawnością. Ratyfikowana przez Polskę w 2012 roku konwencja ONZ o prawach osób 
niepełnosprawnych (Dz.U. z dnia 25 października 2012 r., poz. 1169), odnosząca się w art. 24 ust. 2 wprost do systemu ich kształcenia zakłada, iż „osoby niepełnosprawne będą korzystać z włączającego, bezpłatnego nauczania obowiązkowego wysokiej jakości, na poziomie podstawowym i średnim, na zasadzie równości z innymi osobami w społecznościach, w których żyją" (tamże). W dokumentach strategicznych rozwoju naszego kraju przewiduje się, że do 2020 roku odsetek dzieci niepełnosprawnych uczęszczających do szkół ogólnodostępnych w relacji do ogólnej liczby dzieci niepełnosprawnych objętych edukacją szkolną wzrośnie o 2,9\%. Dokumenty te to Uchwała Nr 104 Rady Ministrów z dnia 18 czerwca 2013 r. w sprawie przyjęcia Strategii Rozwoju Kapitału Ludzkiego 2020 (Monitor Polski z 2013 r., Poz. 640) oraz Uchwała Nr 157 Rady Ministrów z dnia 25 września 2012 r. w sprawie przyjęcia Strategii Rozwoju Kraju 2020 (Monitor Polski z 2012 r., Poz. 882).

Zatem aby idea inkluzji mogła się urzeczywistnić, konieczne jest odpowiednie przygotowanie środowiska włączającego. Niestety mimo wieloletnich starań szeregu instytucji państwowych i samorządowych działających na rzecz osób z niepełnosprawnością wciąż istnieją przeszkody uniemożliwiające im korzystanie z pełni praw i wolności oraz utrudniające im pełne uczestnictwo w życiu społecznym. Jak zauważają Aldona Frączkiewicz-Wronka i Maria Zrałek (2015, s. 102), „problem występowania barier i ich konsekwencji staje się jednym z najważniejszych elementów rozpatrywania warunków równoprawnego uczestnictwa i integracji osób niepełnosprawnych". W cytowanym przez autorki komunikacie Komisji Wspólnoty Europejskiej W kierunku Europy bez barier dla osób z niepetnosprawnościa uznano, że „bariery środowiskowe (społeczne, ekonomiczne, fizyczne) są większą przeszkodą uczestnictwa osób niepełnosprawnych w życiu społecznym niż ich ograniczenia wynikające z niepełnosprawności” (tamże). Konieczność likwidacji barier, szczególnie tych społecznych, implikuje potrzebę przygotowania środowiska edukacyjnego sprzyjającego włączaniu osób z niepełnosprawnością. Zdaniem Andrzeja Pieleckiego (2013, s. 11):

Szkoła i rodzina są bardzo ważnymi miejscami budowania systemu wartości i kształtowania postaw. Oczekuje się, że uczeń współczesnej szkoły będzie posiadał umiejętność dostrzegania takich wartości, jak: poszanowanie prawdy i godności człowieka, dobroć, akceptacja różnic, współdziałanie i dążenie do ich realizacji. Przed nauczycielem stoi ważne zadanie - budowanie wspólnie z rodziną i środowiskiem postaw młodych ludzi, które pozwolą godnie żyć im samym i innym $z$ nimi.

Proces kształtowania się postaw jest ściśle związany z procesem uczenia się, dlatego niezwykle istotnym zagadnieniem jest właściwa jego organizacja. Ponie- 
waż, jak zauważa profesor Jo Jerg (www.dw.com), „inkluzja społeczna zaczyna się w naszych głowach", działania zmierzające do przygotowania środowiska włączającego osoby z niepełnosprawnością w szeroki nurt życia społecznego powinny obejmować kształtowanie odpowiednich postaw.

\section{PROBLEMATYKA BADAŃ WŁASNYCH}

W ramach autorskiego projektu badawczego przeprowadzonego pod roboczym tytułem „Inni? Tacy sami?” zaplanowano szereg działań opartych na eksperymencie pedagogicznym, których celem była analiza wiedzy uczniów ogólnodostępnej szkoły podstawowej na temat osób z niepełnosprawnością oraz przejawianych wobec nich postaw. Starano się ponadto dociec, czy wprowadzenie odpowiednego programu edukacyjnego obejmującego problematykę funkcjonowania osób z różnymi rodzajami niepełnosprawności spowoduje wzrost wiedzy uczniów i zmianę ich postaw w stosunku do tej grupy osób. Badania prowadzone były w drugim semestrze roku szkolnego 2014/2015 w Prywatnej Szkole Podstawowej w Milanówku i obejmowały uczniów z klas I-VI. Łącznie badaniem objęto 77 uczniów z tej szkoły.

Problemy badawcze wyrażono za pomocą następujących pytań:

1. Jaki jest poziom wiedzy uczniów szkoły podstawowej o osobach z niepełnosprawnością przed przeprowadzeniem programu edukacyjnego i po nim?

2. Jakie są postawy uczniów szkoły podstawowej wobec osób niepełnosprawnych?

3. Czy i w jakim zakresie uległy one zmianie po realizacji programu edukacyjnego?

W związku z tym, że projekt wiązał się także z osiągnięciem celów wychowawczych szkoły, przygotowane zajęcia edukacyjne miały także:

- uwrażliwić uczniów na zagadnienie niepełnej sprawności;

- motywować do przełamywania barier i lęku przed kontaktem z osobami niepełnosprawnymi;

- zachęcać do burzenia funkcjonujących w świadomości społecznej stereotypów dotyczących osób niepełnosprawnych;

- skłonić do refleksji nad postawami wobec inności czy różnorodności oraz własnych zachowań w aspekcie ochrony zdrowia.

Podstawową metodą badawczą był eksperyment pedagogiczny. Tadeusz Pilch (1995, s. 43-45) definiuje go następująco:

[...] to taka metoda badawcza, która bada określony wycinek rzeczywistości, pobudzając go do zmian. Zmiany te dotyczą zachodzących w tej rzeczywistości 
wychowawczej procesów wychowawczych i dokonują się pod wpływem nowych czynników, które są do tej rzeczywistości wprowadzane w trakcie badań. Następuje również obserwacja tych zmian w eksperymencie pedagogicznym.

W ramach tej metody wykorzystano technikę jednej grupy polegającą na wprowadzeniu do zastanej sytuacji czynnika eksperymentalnego, a następnie na mierzeniu zmian powstałych pod jego wpływem w taki sposób, aby było możliwe porównanie stanu początkowego ze stanem końcowym (Zaczyński 1967). W celu zebrania danych językowych mających ocenić opisywany aspekt postrzegania przez badanych uczniów osób z niepełnosprawnością wykorzystano metodę swobodnych skojarzeń w tzw. wersji otwartej. Uzyskanie odpowiedzi na postawione pytania badawcze oraz uchwycenie zmian zmiennej zależnej, które wystąpiły w wyniku realizowanego eksperymentu pedagogicznego, możliwe było dzięki wykorzystaniu techniki ankietowania, analizy treści i techniki projekcyjnej (rysunek), rozmowy ustrukturyzowanej oraz następujących narzędzi badawczych:

- Kwestionariusza Wiedzy na Temat Osób Niepełnosprawnych Andrzeja Pieleckiego,

- Dyferencjału semantycznego (w wersji Urszuli Jakubowskiej),

- Testu Zdań Niedokończonych.

\section{Kwestionariusz wiedzy na temat osób niepełnosprawnych (A. Pielecki)}

Kwestionariusz składa się z 35 zdań zamkniętych dotyczących wiedzy o osobach: niewidomych, z uszkodzeniami słuchu, z niepełnosprawnością intelektualną, słabowidzących oraz z niepełnosprawnością ruchową. Na każdą niepełnosprawność przypada 7 stwierdzeń, które związane są z następującymi sferami życia osób niepełnosprawnych: samoobsługa, uczenie się, przyjaźń/miłość, kontakty, praca, sport, lokomocja. W odniesieniu do osób z uszkodzonym słuchem autor kwestionariusza zastąpił zdanie dotyczące lokomocji twierdzeniem o porozumiewaniu się. Dla każdego z twierdzeń przypisano trzy lub cztery odpowiedzi, z których tylko jedna jest prawdziwa. Zadaniem badanego jest zaznaczenie umieszczonej obok odpowiedzi litery P (Prawda) lub F (Fałsz). Każdej prawidłowej odpowiedzi przypisuje się liczbę 1, a błędnej - 0. Ogólny poziom wiedzy badanego na temat poszczególnych rodzajów niepełnosprawności oblicza się, sumując liczbę wszystkich uzyskanych punktów (Pielecki 2013). 


\section{Dyferencjał semantyczny (w wersji U. Jakubowskiej)}

Dyferencjał semantyczny jest wielowymiarową skalą do badania postaw wobec określonych obiektów (ludzi, zdarzeń, przedmiotów) oraz percepcji tych obiektów. Twórcami tej techniki są Charles E. Osgood, George I. Suci i Percy H. Tannebaum (za: Czapiński 1978). Służy ona do pomiaru konotacyjnego znaczenia pojęć. Znaczenie konotacyjne rozumiane jest jako zbiór cech określanych łącznie przez daną nazwę, ale niewyznaczających jednoznacznie zakresu tej nazwy (jakie to jest?). Pozwala opisać dane pojęcie, ale bardziej w wymiarze emocjonalnym niż treściowym, dlatego dyferencjał umożliwia przeprowadzenie analizy, której celem jest ustalenie emocjonalnego stosunku jednostki lub grupy do konkretnego pojęcia.

Dyferencjał semantyczny w wersji Jakubowskiej (1993) określa różnice w znaczeniu afektywnym pojęcia „ja” w stosunku do pojęcia „inni ludzie”. Do badań wykorzystano narzędzie zaprezentowane w pracy Pieleckiego (2013), w którym w zakres pojęcia „inni ludzie” włączono pojęcie „kolega” oraz pojęcia określające osoby o różnych rodzajach niepełnosprawności: osoba niewidoma, osoba słabowidząca, osoba niesłysząca, osoba z niepełnosprawnością intelektualną, osoba na wózku. Każdy z wymienionych obiektów opisany był przez siedem par wyrazów o przeciwstawnym znaczeniu. Zadaniem badanego była ocena wymienionych obiektów przez zaznaczenie jednej z siedmiu pozycji. Ocenom tym przypisywano cyfry od 1 (dla przymiotnika negatywnego) do 7 (dla przymiotnika pozytywnego). Wynik ogólny stanowiła suma punktów uzyskanych we wszystkich dwubiegunowych skalach.

\section{Test zdań niedokończonych}

Zastosowany w badaniach test zdań niedokończonych, wzorowany na teście Juliana B. Rottera, składał się z 24 zdań. Badany musiał dokończyć tzw. trzony zdań, czyli początki zdań zapisanych na karcie odpowiedzi. Uzyskane w ten sposób informacje stały się podstawą do interpretacji prezentowanych przez badanego postaw, zachowań, obaw czy lęków wobec osób z niepełnosprawnością. Każde stwierdzenie w teście było analizowane przez sędziów kompetentnych. Ocena zakończeń miała charakter ilościowy i dokonywana była za pomocą pięciostopniowej skali, gdzie cyfra 1 oznaczała opinię czy postawę bardzo negatywną, 2 - negatywną, 3 - obojętną, 4 - pozytywną, a 5 - bardzo pozytywną.

\section{ORGANIZACJA BADAŃ WŁASNYCH}

Realizacja założeń badawczych obejmowała przeprowadzenie zajęć o charakterze warsztatowym z uczniami wszystkich klas biorących udział w projekcie szkoły 
podstawowej. Organizacja zajęć dostosowana została w związku z tym do możliwości percepcyjnych uczniów. Uwzględniając wiek uczniów, przygotowano 3 programy edukacyjne, odpowiednio dla klas I i II, III i IV oraz V i VI. Zajęcia prowadzone były z wykorzystaniem różnorodnych technik i metod pracy, wśród których dominowały: rozmowa kierowana, pogadanka, opowiadanie, wyjaśnienie, prezentacje multimedialne, filmy instruktażowe, dokumentalne i fabularne poruszające problematykę funkcjonowania osób z różnymi rodzajami niepełnosprawności, drama i psychodrama, doświadczanie ograniczeń w funkcjonowaniu osób z niepełnosprawnością (np. spacer z długą białą laską), ćwiczenia (próby samodzielnego zapisu pismem Braille’a, próby posługiwania się językiem migowym), praca z tekstem, prace plastyczne. Zajęcia $\mathrm{z}$ każdą z klas odbywały się średnio raz w tygodniu i trwały 45 minut. W sumie przeprowadzono 40 spotkań z uczniami.

Ponieważ, jak już wspomniano wyżej, w badaniu zastosowano metodę eksperymentu pedagogicznego, w celu uchwycenia zmian poziomu wiedzy i postaw badanych uczniów wobec osób z niepełnosprawnością na pierwszych spotkaniach dokonano pomiaru początkowego $z$ użyciem opisanych technik i narzędzi badawczych. Procedurę powtórzono na ostatnim spotkaniu $\mathrm{z}$ każdą $\mathrm{z}$ badanych grup.

\section{PREZENTACJA WYNIKÓW BADAŃ}

Prezentowany artykuł jest tylko wstępnym komunikatem z badań, które są w dalszym ciągu kontynuowane, więc zostaną w nim przedstawione tylko częściowe rezultaty z dotychczas przeprowadzonych analiz. Uzyskane dane sugerują bowiem konieczność bardziej pogłębionych eksploracji i nie uprawniają do wyciągnięcia jednoznacznych wniosków. Niemniej wyniki pozwalają uchwycić pewne istotne pozytywne tendencje ukierunkowujące cele pracy edukacyjnej.

\section{Poziom wiedzy uczniów szkoły podstawowej na temat osób niepełnosprawnych przed przeprowadzonymi zajęciami edukacyjnymi i po nich}

1. Osoba z niepełnosprawnością oczami uczniów siedmio- i ośmioletnich

Jak już wspomniano, badani uczniowie byli podzieleni na trzy grupy wiekowe, dla których dopasowano zarówno program edukacyjny, jak i stosowane metody i narzędzia badawcze. Poziom wiedzy o osobach niepełnosprawnych w grupie dzieci najmłodszych, tj. uczniów klas I i II, oceniano na podstawie ich swobodnych wypowiedzi podczas rozmowy kierowanej na temat osób z niepełnosprawnością. Osoba towarzysząca podczas badania notowała wypowiedzi uczniów tak, aby prowadzący rozmowę mógł swobodnie odpowiadać na spontaniczne reakcje dzieci. Podczas 
rozmowy pytano dzieci, kim jest osoba niepełnosprawna, jakie ma cechy, jakie ma możliwości, a co jest dla niej trudne. Uczniom stworzono także warunki, aby mogli swobodnie wyrazić nie tylko werbalnie, ale i graficznie swoje opinie na temat osób niepełnosprawnych. W ten sposób zebrano materiał badawczy stanowiący przesłankę do stworzenia obrazu osób z niepełnosprawnością w opiniach dzieci siedmioletnich i ośmioletnich przed zrealizowaniem programu edukacyjnego i po nim.

Wypowiedzi uczniów klas I i II bardzo obrazowo prezentują ich wiedzę na temat osób z niepełnosprawnością. Uzyskane dane wskazują, że badane dzieci przed rozpoczęciem zajęć edukacyjnych, odpowiadając na pytania o osobę niepełnosprawną (werbalnie i w formie rysunku), w większości (ponad 89\% dzieci siedmioletnich i ponad $82 \%$ dzieci ośmioletnich) określały ją jako wyłącznie osobę z niepełnosprawnością ruchową. Podawane przez uczniów charakterystyki osób z niepełnosprawnością podkreślały głównie aspekt braku, defektu fizycznego oraz niemożności wykonywania pewnych czynności. Dla uczniów z klas I i II osoba niepełnosprawna to taka, „która nie może chodzić, biegać, skakać”, to osoby, które „są na wózkach”, „które nie mogą chodzić albo urodziły się bez części ciała”, „mają taką laskę do podpierania”, „nie mogą bawić się i biegać”, „tylko tak siedzą na takim innym wózku, innym niż dzidziusie”. Z większości początkowych wypowiedzi uczniów siedmio- i ośmioletnich wyłania się uogólniony, stereotypowy obraz osoby z niepełnosprawnością - osoby na wózku inwalidzkim czy posiadającej wyraźny defekt fizyczny, np. „osoba, która ma roborękę”, „osoba, która nie ma jakiejś części ciała". Analiza wypowiedzi uczniów wskazuje ponadto, że przypisywane niepełnosprawnym cechy odnoszone były głównie do aktualnych ich potrzeb i aktywności, co wyraźnie ilustrują przytoczone wypowiedzi. Uczniowie klas młodszych charakteryzowali często osoby z niepełnosprawnością za pomocą cech, które uważają za najbardziej istotne (np. możliwość zabawy), pomijali natomiast te przymioty, którymi określają człowieka dorośli. Zaledwie po 3\% badanych uczniów tej grupy wiekowej wskazywało jako niepełnosprawną osobę niewidomą. Charakterystyczne także dla najmłodszej grupy uczniów było uznawanie za niepełnosprawne również osoby z czasowym uszkodzeniem (np. złamaniem nogi lub ręki). Uważali oni bowiem, że nawet okresowe „unieruchomienie” jest niepełnosprawnością. Takiego zdania było 5\% pierwszoklasistów i 8\% uczniów z klasy II. Część badanej grupy wiekowej (3\% siedmio- i 7\% ośmiolatków) do charakterystyki osób z niepełnosprawnością włączała pojęcie choroby, niemniej bliżej nieokreślonej.

Interesujący jest fakt, że uczniowie, w pierwszym badaniu podając opisowe określenia osoby z niepełnosprawnością, koncentrując się głównie na aspektach fizycznych, nie używali przymiotników oceniających. Często trudno jest doszukać się w tych wypowiedziach emocjonalnego stosunku badanych do osób niepełnosprawnych. Ponadto wypowiedzi te cechowała ogromna zwięzłość. W większości były to 
wypowiedzi jednozdaniowe, często wręcz równoważniki zdań. Można przypuszczać, że wynikać to mogło w głównej mierze z bariery emocjonalnej oraz pewnej niewiedzy w obszarze dokonywanych opisów. Podobne wnioski sugerują analizy prac plastycznych. Pierwsze rysunki wykonywane przez uczniów klas I i II były bardzo schematyczne, najczęściej jednobarwne, z małą ilością szczegółów. Przedstawiały w centralnym punkcie osobę z niepełnosprawnością (najczęściej siedzącą na wózku lub poruszającą się o kulach) lub jakiś „atrybut niepełnosprawności” (np. kule, wózek inwalidzki, protezę ręki). Uczniowie mimo zachęty do kontynuowania pracy nie poświęcili jej zbyt dużo czasu. Najczęściej kończyli ją już po kilku minutach. Wykonane prace plastyczne stanowiły prezentacje stereotypowego postrzegania osoby z niepełnosprawnością.

Analiza wypowiedzi i wytworów plastycznych uczniów po przeprowadzonym programie edukacyjnym wprowadza nowe aspekty opisów (por. tabela 1).

Tabela 1. Wiedza uczniów siedmio- i ośmioletnich na temat osób z niepełnosprawnością. Przykłady wypowiedzi

\begin{tabular}{|l|l|}
\hline \multicolumn{2}{|c|}{ Kto to jest osoba niepełnosprawna? } \\
\hline Pomiar początkowy & Pomiar końcowy \\
\hline To taka osoba co ma „roborękę”. & $\begin{array}{l}\text { Osoba niepełnosprawna to taka, która nie może chodzić, biegać, skakać, } \\
\text { widzieć lub słyszeć i mówić. Czasem mniej rozumie. Można się z nimi } \\
\text { fajnie bawić. }\end{array}$ \\
\hline To ludzie chorzy. & $\begin{array}{l}\text { Osoba niepełnosprawna to jest np. osoba, która nie może chodzić, widzieć } \\
\text { albo mówić. }\end{array}$ \\
\hline To taki ktoś, kto jeździ na wózku. & $\begin{array}{l}\text { Osoby niepełnosprawne są na wózkach, nie mówią, nie widzą. Potrafią } \\
\text { dużo rzeczy zrobić same. Mogą mieć takiego specjalnego psa. }\end{array}$ \\
\hline On nie umie nic zrobić. & $\begin{array}{l}\text { Osoba niepełnosprawna to człowiek, który nie umie chodzić, mówić, nie } \\
\text { umie biegać, nie umie skakać na jednej nodze, ale może być bardzo fajnym } \\
\text { kolegą lub koleżanką. }\end{array}$ \\
\hline Może nie mieć nogi albo ręki. & $\begin{array}{l}\text { Osoba niepełnosprawna to taka, która nie umie chodzić, taka, która nie } \\
\text { umie mówić, taka, która nie umie liczyć, czytać i pisać. }\end{array}$ \\
\hline Jest biedny, bo nie umie biegać. & $\begin{array}{l}\text { To taka osoba, która nie widzi, bo miała wypadek, czy coś. To taka osoba, } \\
\text { która nie może chodzić albo się urodziła bez części ciała. }\end{array}$ \\
\hline Ma jedną nogę i taką laskę. & $\begin{array}{l}\text { Osoba niepełnosprawna zachowuje się dziwnie, wpycha się w kolejce } \\
\text { i wrzeszczy. Ta osoba może się czegoś nauczyć. Można się nauczyć z nią } \\
\text { bawić, ale trudno trochę. Jak się chcesz z nią pobawić to patrzysz na nią, } \\
\text { a ona nie patrzy. Jak ktoś przytuli osobę niepełnosprawną, to ją to boli. } \\
\text { Zeby ona mogła coś zrobić, to jej się pokazuje obrazki. }\end{array}$ \\
\hline
\end{tabular}

Analiza wypowiedzi uczniów klas I i II po przeprowadzonych zajęciach na temat funkcjonowania osób z różnymi rodzajami niepełnosprawności wskazuje na następujące zmiany:

- obok podawanej przez uczniów informacji opisowej (o cechach osoby z niepełnosprawnością np. „nie umie chodzić”) pojawiły się elementy 
oceniające (zawierające informacje o jej wartości, np. „może być fajnym kolegą lub koleżanką");

- większość uczniów (ponad 74\% siedmioletnich i ponad 83\% ośmioletnich) zaczęło dostrzegać u osób niepełnosprawnych nie tylko cechy fizyczne (dotyczące wyglądu zewnętrznego, sposobu poruszania się, stanu zdrowia), ale i te związane z możliwościami intelektualnymi, emocjami, a także $z$ ich zachowaniem wobec innych;

- część badanych uczniów zaczęła włączać w prezentowane charakterystyki osób z niepełnosprawnością metody usprawniania ich funkcjonowania (np. komunikacja za pomocą piktogramów);

- zdecydowana większość opisów (93\%) obejmuje większą różnorodność rozpoznawanych deficytów: można w nich doszukać się charakterystyk niepełnosprawności fizycznej, sensorycznej, intelektualnej, a także zaburzeń ze spektrum autyzmu.

Wyraźne zmiany zauważono także w projekcjach plastycznych badanych uczniów. Tym razem, przedstawiając osobę z niepełnosprawnością, starali się oni umieścić ją w odpowiednim kontekście sytuacyjnym. Duża część rysunków (86\% prac) przedstawiała osobę $\mathrm{z}$ niepełnosprawnością podczas zabawy $\mathrm{z}$ rówieśnikami na placu zabaw, na spacerze z psem czy w szkole. W każdym przypadku na twarzy rysowanych osób widoczny był uśmiech. Ich postacie bogate były w szczegóły (wyraźne detale garderoby, ozdoby we włosach) i wielobarwne. To, czego brakowało w poprzednich pracach, to duża dbałość o „estetyczne otoczenie” miejsc, w których prezentowane były osoby niepełnosprawne - piękne parki z dużą ilością drzew, place zabaw, bogato wyposażone pomieszczenia. Jedyną cechą odróżniającą na obrazku osobę niepełnosprawną od innych na nim prezentowanych był wózek inwalidzki czy laska, czyli przedmioty wskazujące na rodzaj dysfunkcji. Zarówno sposób przedstawienia, wielkość, dobór barw, jak i miejsce zajmowane na obrazku sugerują równe traktowanie wszystkich widniejących na nim postaci. Zaledwie jedna praca wyróżniała się na tle innych bardzo podobnych. Jeden z uczniów przedstawił na dużej kartce papieru małą czarną postać z uniesionymi do góry rękoma, wokół której (na wysokości jej pasa) narysował strzałki sugerujące ruch obrotowy. Była to jego projekcja wrażeń związanych z osobą z autyzmem. Wszystkie pozostałe prace tak jak w badaniu początkowym skupiały się głównie na osobach z niepełnosprawnością ruchową oraz niewidomych. W porównaniu z pierwszymi pracami uczniowie ilustrujący graficznie pojęcie „osoba niepełnosprawna” po zakończeniu cyklu zajęć edukacyjnych poświęcili temu zadaniu znacznie więcej czasu (około 25 minut) i wykazywali dużo większe zaangażowanie w podjętą pracę.

Przedstawione wyżej wyniki wskazują na przyrost wiedzy biorących udział $\mathrm{w}$ eksperymencie uczniów na temat funkcjonowania osób z różnymi rodzajami 
niepełnosprawności wpływający na większą swobodę i chęć wypowiadania się na wskazany temat oraz zmniejszenie się emocjonalnego dystansu wobec omawianych zagadnień. Potwierdzeniem tej tezy są także obserwacje i odczucia prowadzącego zajęcia z dziećmi eksperymentatora. Uczniowie na kolejnych spotkaniach otwierali się na zagadnienia niepełnej sprawności, wykazywali coraz więcej chęci pogłębiania wiedzy. Z relacji wychowawców klas wiadomo także, że kilkoro uczniów dotychczas milczących na temat niepełnosprawności rodzeństwa zaczęło otwarcie, na forum klasy opowiadać o własnym w tym aspekcie doświadczeniu.

2. Osoby z niepełnosprawnością w opiniach uczniów klas III i IV

Poznanie postaw wobec osób z niepełnosprawnością oraz ich zmian w wyniku przeprowadzonego programu edukacyjnego „Inni? Tacy sami?” w grupie uczniów z klas III i IV możliwe było dzięki wykorzystaniu rozmowy według wcześniej przygotowanych dyspozycji. Rozmowa obejmowała 10 pytań odnoszących się do $3 \mathrm{kom}$ ponentów postaw wobec osób z niepełnosprawnością: poznawczego, emocjonalnego i behawioralnego.

Analiza materiału empirycznego wykazała występowanie czterech grup opisów pojawiających się w wypowiedziach badanych uczniów dziewięcio- i dziesięcioletnich na temat osób z niepełnosprawnością. Uczniowie poproszeni o zdefiniowanie, kim jest osoba niepełnosprawna, najczęściej udzielali odpowiedzi:

- będących opisem osoby z niepełnosprawnością przez wskazywanie rodzaju ich dysfunkcji;

- podkreślających niemożność wykonywania przez osoby niepełnosprawne większości czynności dnia codziennego, wskazujących na występowanie różnic w tym aspekcie między nimi a osobami w pełni sprawnymi;

- stanowiących terminy zbliżone znaczeniowo, niemniej nacechowane pejoratywnie (np. „osoba z wadą”, „kaleka”, „inwalida”, „osoba poszkodowana");

- wskazujących na nieumiejętność bądź niechęć do wyjaśniania, kim są osoby niepełnosprawne (brak odpowiedzi na pytania, niedokończenie zdań czy przyznawanie się do niewiedzy) (por. diagram 1).

W obrazie osób niepełnosprawnych, ujawnionym w wypowiedziach uczniów klas III i IV w pomiarze początkowym, dominuje stereotyp osoby niesprawnej fizycznie, potrzebującej pomocy, mającej trudności z porozumiewaniem się z innymi. Opisując osoby niepełnosprawne, połowa badanych uczniów tej grupy wiekowej wskazywała na niemożność wykonywania przez nie większości czynności. Była to dla nich główna cecha różniąca grupy osób pełnosprawnych i niepełnosprawnych. Uczniowie poproszeni o dokończenie zdania „Osoba niepełnosprawna....” podawali 
następujące charakterystyki: „Nie umie wszystkiego, co osoba pełnosprawna”, „Nie może wszystkiego robič”, „To osoba, która czegoś nie wypełnia”, „To osoba, która nic nie potrafi”, „To osoba nieumiejąca różnych rzeczy”, „To osoba, która nie umie większości rzeczy”, „To osoba, która nie może różnych czynności” (por. tabela 2).

Czy wiesz, kto to jest osoba niepełnosprawna?

$(\mathrm{N}=30)$

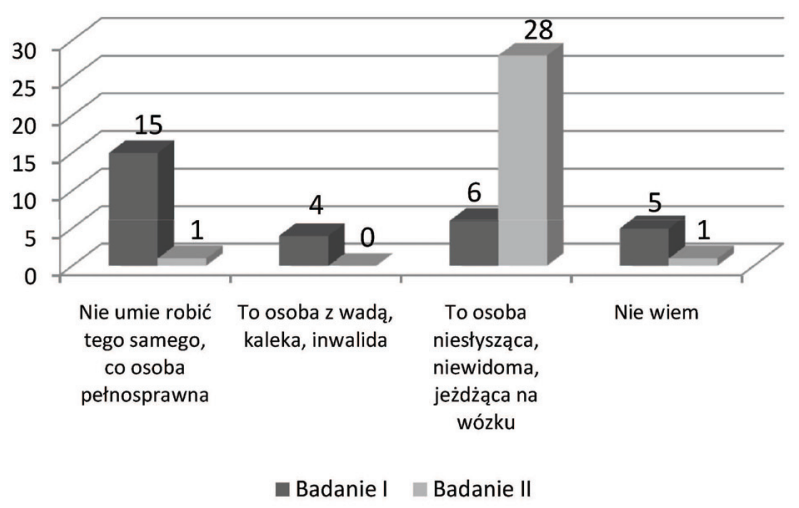

Diagram 1. Rozkład odpowiedzi uczniów klas III i IV na pytanie „Czy wiesz, kto to jest osoba niepełnosprawna?”

Opierając się na analizach przeprowadzonych przez Anettę Sorokę-Fedorczuk (2007, s. 110), w omawianych badaniach w celu zobrazowania dziecięcych opisów wzięto pod uwagę także liczbę określeń stosowanych w przedstawianych charakterystykach oraz znajomość rodzajów niepełnosprawności. Zgodnie z tymi kryteriami po pierwszym pomiarze wyróżniono dwie grupy:

1. Dzieci definiujące wąsko osoby niepełnosprawne - w opisach stosowały małą liczbę określeń (od 1 do 2); dotyczyły one najczęściej jednego rodzaju niepełnosprawności, głównie fizycznej (np. „To człowiek, który jest na przykład na kulach”, „Osoba, która jeździ na wózku, która nie ma nóg”, „To osoba np. sparaliżowana”) i sensorycznej (np. „To taka osoba, która np. nie słyszy”, „To osoba, która nie słyszy, nie widzi”). Grupa dominowała, stanowiła 83\% uczniów dziewięcio- i dziesięcioletnich.

2. Dzieci niepotrafiące opisać osób niepełnosprawnych - najczęściej unikały udzielenia odpowiedzi przez stwierdzenie „nie wiem”. Taki poziom wiedzy na temat osób z niepełnosprawnością cechował 17\% uczniów klas III i IV.

Po przeprowadzonych zajęciach edukacyjnych wyłoniła się nowa dominująca grupa dzieci (93\%) opisujących szeroko osoby niepełnosprawne - ich charakte- 
rystyki były bogatsze, świadczyły o większej znajomości problemów dotyczących osób niepełnosprawnych. Liczba określeń w wypowiedziach zwiększyła się (powyżej 3). Uczniowie zaczęli przypisywać osobom niepełnosprawnym cechy zarówno fizyczne, jak i psychiczne, operowali pojęciami świadczącymi o pewnej znajomości różnych rodzajów niepełnosprawności i ich konsekwencji psychospołecznych (por. diagram 1, tabela 2).

Tabela 2. Wiedza uczniów dziewięcio- i dziesięcioletnich na temat osób z niepełnosprawnością. Przykłady wypowiedzi

\begin{tabular}{|l|l|}
\hline \multicolumn{2}{|c|}{ Kto to jest osoba niepełnosprawna? } \\
\hline Pomiar początkowy & Pomiar końcowy \\
\hline Nie wiem. & $\begin{array}{l}\text { To taka osoba, która np. ma problemy z poruszaniem się lub osoba niewi- } \\
\text { doma, lub osoba z autyzmem itp. }\end{array}$ \\
\hline Która prawie nie umie nic robić. & $\begin{array}{l}\text { To osoba, która np. nie słyszy, nie widzi do końca, ma autyzm. Ma dużo } \\
\text { problemów, a potrafi sobie radzić z nimi. }\end{array}$ \\
\hline $\begin{array}{l}\text { Nie umie wszystkiego, co osoba } \\
\text { pełnosprawna. }\end{array}$ & To osoba, która potrzebuje pomocy. \\
\hline $\begin{array}{l}\text { Nie umie robić tego wszystkiego, } \\
\text { co my. }\end{array}$ & Osoba, która nie może normalnie funkcjonować. \\
\hline $\begin{array}{l}\text { Osoba, która jeździ na wózku, } \\
\text { która nie ma nóg. }\end{array}$ & To osoba, która ma problemy zdrowotne. \\
\hline Ta osoba to inwalida. & To osoba, która nie słyszy, nie widzi, nie może chodzić. \\
\hline $\begin{array}{l}\text { To osoba, która czegoś nie wy- } \\
\text { pełnia. }\end{array}$ & To taka, która np. nie słyszy. \\
\hline
\end{tabular}

Jak możemy pomóc osobom niepełnosprawnym?

$$
(\mathrm{N}=30)
$$

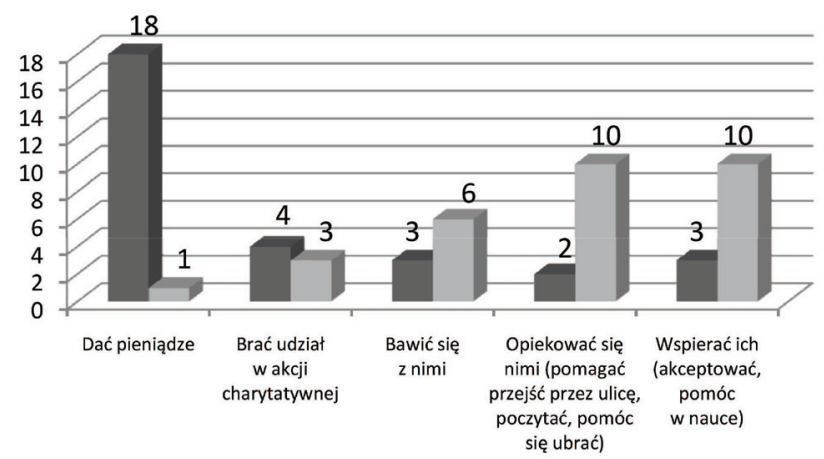

Badanie I Badanie II

Diagram 2. Rozkład odpowiedzi uczniów klas III i IV na pytanie „Jak możemy pomóc osobom niepełnosprawnym?” 
Ciekawe wyniki przyniosły analizy pytania dotyczącego pomocy osobom z niepełnosprawnością. Zdecydowana większość uczniów (58\%) przed rozpoczęciem zajęć edukacyjnych twierdziła, że najlepszą formą pomocy osobie z niepełnosprawnością jest ofiarowanie jej pieniędzy. Taką odpowiedź po przeprowadzonym programie wskazywał już tylko $1 \mathrm{z}$ badanych uczniów. Oddziaływania edukacyjne zwróciły uwagę dzieci na inne aspekty pomocy i wsparcia. W ich wyniku w wypowiedziach uczniów klas III i IV biorących udział w eksperymencie dominowały odpowiedzi związane ze wsparciem społecznym i emocjonalnym (po 33\% odpowiedzi) (diagram 2).

Chcąc ocenić aspekt emocjonalny i behawioralny postaw badanej grupy uczniów wobec osób z niepełnosprawnością, zapytano ich o chęć podjęcia wspólnej zabawy. Zarówno pierwsze, jak i drugie badanie pokazuje, że zdecydowana większość uczniów bardzo chętnie włączyłaby do niej także dzieci z niepełnosprawnością (83\% uczniów po I badaniu i $90 \%$ po II badaniu). Dwóch uczniów podczas pierwszej rozmowy wyraziło obawę przed taką zabawą i również 2 wskazało na chęć sprawdzenia, „jak to by było". Tylko 1 uczeń w badaniu początkowym nie wyraził chęci wspólnej zabawy z dzieckiem niepełnosprawnym. Zdanie to zmienił w badaniu końcowym na korzyść „wypróbowania” takiej sytuacji (diagram 3).

Gdyby dziecko niepełnosprawne chciało się ze mną bawić...

$(\mathrm{N}=30)$

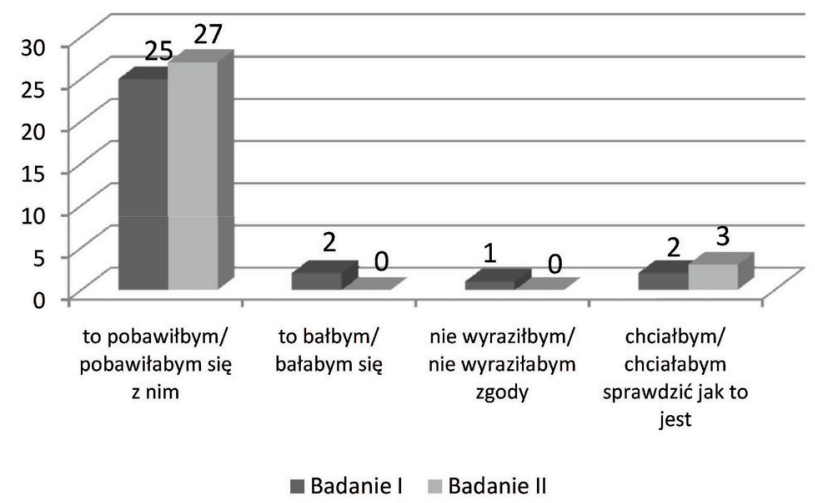

Diagram 3. Rozkład odpowiedzi uczniów klas III i IV na zagadnienie „Gdyby dziecko niepełnosprawne chciało się ze mną bawić...”

Podobnie optymistyczne były odpowiedzi uczniów dziewięcio- i dziesięcioletnich pytanych o to, jak zachowałyby się w sytuacji spotkania z osobą niepełnosprawną. Wszystkie wypowiedzi dzieci, zarówno te w badaniu początkowym, jak i końcowym, miały pozytywny kontekst. Widoczne są jednak pewne różnice 
odnośnie do postulowanych aktywności towarzyszących temu ewentualnemu spotkaniu. W pierwszej rozmowie uczniowie w większości (73\%) deklarowali chęć niesienia pomocy spotkanej osobie niepełnosprawnej bez wskazywania, czego ta pomoc mogłaby dotyczyć i kto byłby inicjatorem takiej propozycji. Grzeczne przywitanie się jako element nawiązania kontaktu wskazało 3 uczniów (10\%) i tyle samo przy pierwszym spotkaniu zaoferowałoby pieniądze. Dwóch uczniów zadeklarowało okazanie akceptacji podczas spotkania z osobą niepełnosprawną. Zajęcia edukacyjne na temat niepełnosprawności, w których brały udział badane dzieci, zmieniły nieco rozkład i treść odpowiedzi. W badaniu końcowym ogólną odpowiedź dotyczącą pomocy osobie z niepełnosprawnością wybrało nieco mniej, bo $53 \%$ badanych z tej grupy. Po 5 uczniów (17\%) wskazało przywitanie się i okazanie akceptacji jako elementy towarzyszące takiemu spotkaniu, natomiast 4 uczniów (13\%) uznało, że przy spotkaniu z osobą niepełnosprawną należy zapytać ją, czego potrzebuje, aby pomoc była bardziej skuteczna i odpowiadała jej rzeczywistym potrzebom. Takich propozycji odpowiedzi nie odnotowano w badaniu początkowym. Nikt też w kolejnym badaniu nie uznał za stosowne oferowanie pieniędzy napotkanej osobie niepełnosprawnej (por. diagram 4).

Co zrobisz, gdy spotkasz osobę niepełnosprawną?

$(\mathrm{N}=30)$

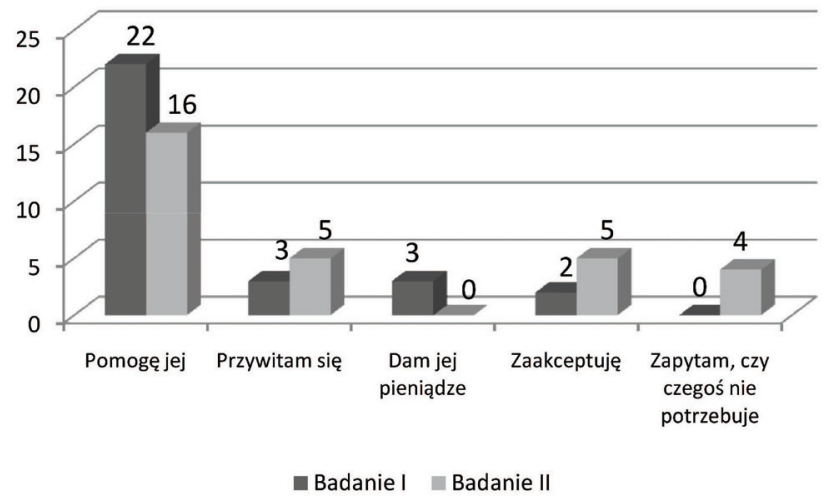

Diagram 4. Rozkład odpowiedzi uczniów klas III i IV na pytanie „Co zrobisz, gdy spotkasz osobę niepełnosprawną?

3. Poziom wiedzy i postawy wobec osób z niepełnosprawnością uczniów klas V i VI

Uczniowie starszych klas szkoły podstawowej, realizując program edukacyjny „Inni? Tacy sami?”, podobnie jak uczniowie klas młodszych poddani zostali 
dwukrotnemu pomiarowi w celu ustalenia jego efektywności. Pomiar poziomu wiedzy i postaw tej grupy wobec osób z niepełnosprawnością możliwy był dzięki zastosowaniu następujących narzędzi badawczych: Testu Wiadomości o Osobach Niepełnosprawnych Pieleckiego, dyferencjału semantycznego, Testu Zdań Niedokończonych. Umożliwiły one ocenę postaw badanych uczniów w zakresie trzech komponentów postawy: poznawczego, emocjonalnego i behawioralnego.

\subsection{Wiedza uczniów klas V-VI na temat osób niepełnosprawnych}

przed zajęciami edukacyjnymi i po nich

Przeprowadzone analizy uzyskanych wyników badań na poziomie wyjściowym i końcowym pozwalają stwierdzić, że przeprowadzone zajęcia spowodowały istotny wzrost wiedzy na temat różnych rodzajów niepełnosprawności u uczniów biorących w nich udział. Okazało się, że średnia odzwierciedlająca wiedzę uczniów klas V i VI jest znacznie wyższa przy pomiarze końcowym przeprowadzonym po odbytych zajęciach edukacyjnych $(X=117,0)$ niż na początku spotkań $(X=113,1)$. Różnica między średnimi jest istotna statystycznie na poziomie p>0,000 (tabela 3).

Biorąc pod uwagę poszczególne rodzaje niepełnosprawności, zauważamy, że nie ma istotnych statystycznie różnic między etapami badań początkowym i końcowym w zakresie wiedzy o osobach niewidomych, słabowidzących, z uszkodzonym słuchem i niepełnosprawnych ruchowo. Jedyna istotna statystycznie różnica wystąpiła w zakresie wiedzy badanych uczniów na temat osób z niepełnosprawnością intelektualną $(\mathrm{t}=-6,364 ; \mathrm{p}>0,000)$. Przeprowadzona analiza pozwala zatem stwierdzić, że w przypadku poziomu wiedzy o osobach z niepełnosprawnością intelektualną program edukacyjny „Inni? Tacy sami?” przyczynił się do znacznego poszerzenia wiedzy uczniów go realizujących o tej grupie osób niepełnosprawnych.

Tabela 3. Średnie wyniki wiedzy badanych uczniów klas V-VI o osobach niepełnosprawnych przed zajęciami edukacyjnymi i po nich

\begin{tabular}{|l|c|c|c|c|c|c|}
\hline \multirow{2}{*}{$\begin{array}{c}\text { Wiedza badanych uczniów o oso- } \\
\text { bach z niepełnosprawnością }\end{array}$} & \multicolumn{2}{c|}{$\begin{array}{c}\text { Pomiar } \\
\text { początkowy }\end{array}$} & \multicolumn{2}{c|}{$\begin{array}{c}\text { Pomiar } \\
\text { końcowy }\end{array}$} & $\mathrm{t}$ & $\mathrm{p} . \mathrm{i}$ \\
\cline { 2 - 8 } & $\mathrm{X}$ & $\mathrm{sd}$ & $\mathrm{X}$ & $\mathrm{sd}$ & & \\
\hline Wiedza o osobach niewidomych & 24,3 & 1,7 & 25,0 & 1,2 & -1.747 & $\mathrm{n} . \mathrm{i}$ \\
\hline Wiedza o osobach słabowidzących & 22,1 & 1,4 & 22,3 & 1,5 & -0.629 & $\mathrm{n} . \mathrm{i}$ \\
\hline Wiedza o osobach z uszkodzonym słuchem & 23,8 & 2,2 & 24,5 & 1,7 & -1.320 & $\mathrm{n} . \mathrm{i}$ \\
\hline Wiedza o osobach niepełnosprawnych ruchowo & 22,7 & 1,6 & 22,9 & 1,8 & -0.454 & n.i \\
\hline Wiedza o osobach z niepełnosprawnością intelektualną & 20,2 & 1,4 & 22,3 & 1,3 & -6.364 & 0.000 \\
\hline Razem & 113,1 & 5,9 & 117,0 & 4,5 & -3.329 & 0.000 \\
\hline
\end{tabular}

$\mathrm{X}$ - średnia arytmetyczna wyników, sd - odchylenie standardowe wyników, $\mathrm{t}$ - wyniki testu t-Studenta, p.i. - poziom istotności 
Choć nieistotne statystycznie, to jednak interesujące zdają się być wyniki porównania średnich wyników uzyskanych przez badanych uczniów w odniesieniu do poszczególnych rodzajów niepełnosprawności. Najwyższe wyniki świadczące o dużym zasobie wiedzy uczniów klas V i VI na temat funkcjonowania osób z niepełnosprawnością zauważa się w odniesieniu do niewidomych $(X=24,3$ pomiar początkowy i $X=25,0$ przy pomiarze końcowym) oraz osób z uszkodzonym słuchem (odpowiednio $X=23,8$ i $X=24,5$ ). Najniższy poziom wiedzy zaobserwowano natomiast w odniesieniu do osób z niepełnosprawnością intelektualną $(X=20,2)$, niemniej potem nastąpił najwyższy istotny przyrost wiedzy na ten temat $\mathrm{w}$ wyniku zrealizowanego programu edukacyjnego $(X=22,3)$ (tabela 3 ).

\subsection{Reakcje emocjonalne uczniów klas V i VI wobec osób z niepełnosprawnością}

Aby określić komponent emocjonalny postaw badanych uczniów wobec osób niepełnosprawnych zastosowano dyferencjał semantyczny. Analiza danych obejmowała porównanie wyników globalnych uzyskanych przed realizacją programu edukacyjnego i po zajęciach z uczniami. Porównanie to dotyczyło siły komponentu emocjonalnego postaw badanych uczniów związanej z określeniami: „ja”, „kolega”, „osoba niepełnosprawna ruchowo”, „osoba niesłysząca”, „osoba niewidoma”, „osoba słabowidząca” oraz „osoba niepełnosprawna intelektualnie”.

Tabela 4. Komponent emocjonalny postawy badanych uczniów jedenasto- i dwunastoletnich przed

przeprowadzonymi zajęciami edukacyjnymi i po nich

\begin{tabular}{|l|c|c|c|c|c|c|}
\hline \multirow{2}{*}{ Pojęcia } & \multicolumn{2}{|c|}{$\begin{array}{c}\text { Pomiar } \\
\text { początkowy }\end{array}$} & \multicolumn{2}{|c|}{$\begin{array}{c}\text { Pomiar } \\
\text { końcowy }\end{array}$} & $\mathrm{t}$ & $\mathrm{p} . \mathrm{i}$ \\
\cline { 2 - 9 } & $\mathrm{X}$ & $\mathrm{sd}$ & $\mathrm{X}$ & $\mathrm{sd}$ & & \\
\hline Ja & 47,4 & 6,05 & 43,6 & 8,40 & 1,366 & n.i. \\
\hline Kolega & 46,3 & 9,21 & 46,7 & 6,94 & $-0,139$ & $\mathrm{n} . \mathrm{i}$. \\
\hline Osoba niewidoma & 46,1 & 5,68 & 47,6 & 8,86 & $-0,507$ & $\mathrm{n} . \mathrm{i}$ \\
\hline Osoba słabowidząca & 41,6 & 8,93 & 44,4 & 5,50 & $-1,018$ & $\mathrm{n} . \mathrm{i}$ \\
\hline Osoba z uszkodzonym słuchem & 43,0 & 7,72 & 44,5 & 5,44 & $-0,537$ & $\mathrm{n} . \mathrm{i}$. \\
\hline Osoba niepełnosprawna ruchowo & 45,7 & 8,55 & 42,1 & 4,25 & 1,398 & n.i. \\
\hline Osoba z niepełnosprawnością intelektualną & 35,4 & 12,57 & 37,5 & 5,73 & $-0,579$ & $\mathrm{n} . \mathrm{i}$ \\
\hline
\end{tabular}

$\mathrm{X}$ - średnia arytmetyczna wyników, sd - odchylenie standardowe wyników, t- wyniki testu t-Studenta, p.i.-poziom istotności

Analiza danych zawartych w tabeli 4 wskazuje, że średnie określające siłę komponentu emocjonalnego postaw badanych uczniów wobec osób z różnymi rodzajami niepełnosprawności uzyskane przed zajęciami na temat niepełnosprawności 
i po nich różnią się, choć jest to różnica nieistotna statystycznie. Zauważyć należy, że w badaniu początkowym średnie określające komponent emocjonalny postawy na hasła „ja”, „kolega” i „osoba niewidoma” są znacznie wyższe niż średnie ukazujące czynnik emocjonalny postawy w odniesieniu do osób słabowidzących, z uszkodzonym słuchem, a zwłaszcza z niepełnosprawnością intelektualną. W przypadku tej ostatniej grupy niepełnosprawnych obserwujemy także najwyższą wartość odchylenia standardowego, co świadczy o największym zróżnicowaniu wyników dotyczących tej grupy. Interesujący jest także fakt, że zajęcia przybliżające uczniom różnorodne aspekty funkcjonowania osób niepełnosprawnych przyczyniły się do wyraźnego obniżenia średniej ukazującej czynnik emocjonalny postawy badanych uczniów do określeń „ja” oraz „osoba niepełnosprawna ruchowo”. Należy również zauważyć, że odchylenia standardowe w odniesieniu do osób z niepełnosprawnością intelektualną, słabowidzących, z uszkodzonym słuchem oraz z niepełnosprawnością ruchową są znacznie mniejsze przy pomiarze końcowym, co może świadczyć o pozytywnym wpływie przeprowadzonych zajęć na zmiany komponentu emocjonalnego postaw wobec tych grup osób.

\subsection{Przewidywane zachowania uczniów klas V i VI wobec osób z niepełnosprawnością}

Komponent behawioralny postaw uczniów klas V i VI ogólnodostępnej szkoły podstawowej wobec osób niepełnosprawnych określono za pomocą zestawu 24 zdań odzwierciedlających stosunek badanych dzieci do niepełnosprawnych. Analiza otrzymanego materiału pozwoliła na określenie, w jaki sposób biorący udział w badaniu jedenasto- $\mathrm{i}$ dwunastolatkowie zachowaliby się w sytuacji bezpośredniego kontaktu z osobami niepełnosprawnymi.

Tabela 5. Komponent behawioralny postawy uczniów klas V-VI przed przeprowadzonymi zajęciami edukacyjnymi i po nich

\begin{tabular}{|c|c|c|c|c|c|c|c|c|}
\hline \multirow[t]{2}{*}{ Lp. } & \multirow[t]{2}{*}{ Zdania } & \multicolumn{2}{|c|}{$\begin{array}{c}\text { Pomiar } \\
\text { początkowy }\end{array}$} & \multicolumn{2}{|c|}{$\begin{array}{l}\text { Pomiar } \\
\text { końcowy }\end{array}$} & \multirow[t]{2}{*}{$\mathrm{Xp}-\mathrm{Xk}$} & \multirow[t]{2}{*}{$\mathrm{t}$} & \multirow[t]{2}{*}{$\mathrm{p}$} \\
\hline & & $\mathrm{Xp}$ & $\mathrm{sd}$ & $\mathrm{Xk}$ & $\mathrm{sd}$ & & & \\
\hline 1. & Kiedy widzę osobę niepełnosprawną, to myślę... & 4,2 & 0,90 & 3,7 & 0,94 & 0,5 & $-0,580$ & n.i. \\
\hline 2. & $\begin{array}{l}\text { Tym, co pomogłoby mi zrozumieć osoby nie- } \\
\text { pełnosprawne, jest... }\end{array}$ & 4,2 & 0,90 & 4,0 & 0,82 & 0,16 & 0,307 & n.i. \\
\hline 3. & $\begin{array}{l}\text { Myślę, że spotkania i dyskusje z osobami nie- } \\
\text { pełnosprawnymi są (dobre, złe, niepotrzebne), } \\
\text { ponieważ... }\end{array}$ & 4,5 & 1,12 & 5,0 & 0,00 & $-0,5$ & $-1,000$ & n.i. \\
\hline 4. & $\begin{array}{l}\text { Najbardziej bałbym się, gdyby osoba niepełno- } \\
\text { sprawna... }\end{array}$ & 3,0 & 1,0 & 3,5 & 1,12 & $-0,5$ & $-0,745$ & n.i. \\
\hline
\end{tabular}




\begin{tabular}{|c|c|c|c|c|c|c|c|c|}
\hline \multirow[t]{2}{*}{ Lp. } & \multirow[t]{2}{*}{ Zdania } & \multicolumn{2}{|c|}{$\begin{array}{c}\text { Pomiar } \\
\text { początkowy }\end{array}$} & \multicolumn{2}{|c|}{$\begin{array}{l}\text { Pomiar } \\
\text { końcowy }\end{array}$} & \multirow[t]{2}{*}{$\mathrm{Xp}-\mathrm{Xk}$} & & \multirow[t]{2}{*}{$\mathrm{p}$} \\
\hline & & $\mathrm{Xp}$ & sd & $\mathrm{Xk}$ & sd & & & \\
\hline 5. & Gdy spotkam osobę niepełnosprawną ... & 3,8 & 0,90 & 3,5 & 0,76 & 0,33 & 0,632 & n.i. \\
\hline 6. & $\begin{array}{l}\text { Najczęstsze błędy, które popełniamy w kontak- } \\
\text { tach z osobami niepełnosprawnymi to... }\end{array}$ & 3,7 & 0,94 & 4,2 & 1,07 & $-0,5$ & $-0,785$ & n.i. \\
\hline 7. & $\begin{array}{l}\text { Kiedy dowiaduję się, że ktoś jest niepełnospraw- } \\
\text { ny... }\end{array}$ & 3,2 & 0,90 & 3,5 & 0,5 & $-0,34$ & $-0,725$ & n.i. \\
\hline 8. & $\begin{array}{l}\text { Uważam, że można pomóc dziecku niepełno- } \\
\text { sprawnemu przez... }\end{array}$ & 4,0 & 0,82 & 3,7 & 0,75 & 0,34 & 0,674 & n.i \\
\hline 9. & Wolałbym, żeby osoby niepełnosprawne... & 3,3 & 1,25 & 4,5 & 0,76 & $-1,17$ & $-1,783$ & n.i. \\
\hline 10. & Filmy o niepełnosprawnych... & 3,5 & 0,96 & 4,8 & 0,37 & $-1,33$ & $-2,902$ & 0,02 \\
\hline 11. & Wiem, że są osoby niepełnosprawne, ale... & 3,0 & 0,58 & 3,3 & 0,94 & $-0,33$ & $-0,674$ & n.i. \\
\hline 12. & $\begin{array}{l}\text { Najbardziej nie lubiłbym, gdyby osoba niepeł- } \\
\text { nosprawna... }\end{array}$ & 3,3 & 0,94 & 3,0 & 1,00 & 0,33 & 0,542 & n.i. \\
\hline 13. & $\begin{array}{l}\text { Byłoby mi bardzo przykro, gdyby osoba niepeł- } \\
\text { nosprawna... }\end{array}$ & 3,3 & 0,94 & 3,0 & 1,00 & 0,33 & 0,542 & n.i. \\
\hline 14. & Bałbym się tego, że osoba niepełnosprawna... & 3,3 & 0,75 & 2,7 & 0,75 & 0,67 & 1,414 & n.i. \\
\hline 15. & $\begin{array}{l}\text { Denerwowałbym się, gdyby osoba niepełno- } \\
\text { sprawna... }\end{array}$ & 3,2 & 0,90 & 3,0 & 0,58 & 0,16 & 0,349 & n.i. \\
\hline 16. & $\begin{array}{l}\text { W towarzystwie osoby niepełnosprawnej czuł- } \\
\text { bym się... }\end{array}$ & 2,5 & 0,76 & 3,2 & 0,69 & $-0,66$ & $-1,450$ & n.i. \\
\hline 17 & $\begin{array}{l}\text { Gdyby osoba niepełnosprawna chciała nawiązać } \\
\text { ze mną kontakt... }\end{array}$ & 4,2 & 0,69 & 4,0 & 0,58 & 0,16 & 0,415 & n.i. \\
\hline 18. & $\begin{array}{l}\text { Zaprosiłbym osobę niepełnosprawną na dysko- } \\
\text { tekę, ale bałbym się ... }\end{array}$ & 3,7 & 0,94 & 3,3 & 1,11 & 0,33 & 0,513 & n.i. \\
\hline 19. & $\begin{array}{l}\text { Zaprosiłbym osobę niepełnosprawną na swoje } \\
\text { urodziny, ale bałbym się ... }\end{array}$ & 3,7 & 0,94 & 3,3 & 0,94 & 0,33 & 0,559 & n.i. \\
\hline 20. & $\begin{array}{l}\text { Nie chciałbym nigdy, żeby osoby niepełno- } \\
\text { sprawne... }\end{array}$ & 3,3 & 0,94 & 3,2 & 0,90 & 0,17 & 0,286 & n.i. \\
\hline 21. & $\begin{array}{l}\text { Łatwiej byłoby mi zrozumieć osoby niepełno- } \\
\text { sprawne... }\end{array}$ & 3,5 & 0,76 & 3,5 & 0,76 & 0,00 & 0,000 & n.i. \\
\hline 22. & $\begin{array}{l}\text { Gdyby ktoś w mojej rodzinie był niepełno- } \\
\text { sprawny... }\end{array}$ & 4,5 & 0,76 & 3,8 & 0,90 & 0,67 & 1,264 & n.i. \\
\hline 23. & $\begin{array}{l}\text { Wydaje mi się, że największą krzywdę niepeł- } \\
\text { nosprawnym można wyrządzić... }\end{array}$ & 4,2 & 0,90 & 4,3 & 0,48 & $-0,17$ & $-0,368$ & n.i. \\
\hline 24. & $\begin{array}{l}\text { Gdybym musiał spędzić cały dzień w towarzy- } \\
\text { stwie osoby niepełnosprawnej... }\end{array}$ & 3,8 & 0,90 & 4,0 & 1,00 & $-0,17$ & $-0,277$ & n.i. \\
\hline
\end{tabular}

$\mathrm{Xp}$ - średnia arytmetyczna pomiaru początkowego, Xk - średnia arytmetyczna pomiaru końcowego, Sd -odchylenie standardowe, $\mathrm{t}$ - wartość testu t-Studenta, p - poziom istotności statystycznej

Analiza danych zawartych w tabeli 5 wskazuje, że spośród 24 itemów poddanych ocenie statystycznej zaledwie w 9 przypadkach badani uzyskali średnie wyniki wyższe w badaniu końcowym w porównaniu z ich odpowiedziami na początku 
spotkań. Jedynie w przypadku zdania: „Filmy o niepełnosprawnych...” różnica ta okazała się istotna statystycznie $(\mathrm{p}>0,02)$. Badani argumentowali, że prezentowane filmy pozwoliły im lepiej zrozumieć osoby z niepełnosprawnością i obaliły wiele obecnych w ich świadomości mitów na temat ich funkcjonowania. Nieistotne statystycznie, ale świadczące o pewnym pozytywnym wpływie programu edukacyjnego, są wysokie wyniki średnie uzyskane przez uczniów kończących zdanie: „Myślę, że spotkania i dyskusje z osobami niepełnosprawnymi są (dobre, złe, niepotrzebne), ponieważ...”. Zdecydowana większość wskazywała na dużą wartość i ogromną potrzebę takich spotkań. Wysokie wyniki średnie wskazujące na oczekiwany pozytywny zamiar zachowania się badanych wobec osób niepełnosprawnych obserwujemy także w odniesieniu do itemów: „Najczęstsze błędy, które popełniamy w kontaktach z osobami niepełnosprawnymi to...”, „Wolałbym, żeby osoby niepełnosprawne...”, „Wydaje mi się, że największą krzywdę niepełnosprawnym można wyrządzić...”. Porównanie jakościowe odpowiedzi uczniów z pierwszego i końcowego badania pokazuje większe zrozumienie potrzeb i emocji osób niepełnosprawnych w relacjach interpersonalnych $\mathrm{z}$ osobami pełnosprawnymi.

\section{PODSUMOWANIE}

Jak zauważa Joanna Głodkowska (2009, s. 7), „podmiotowymi uczestnikami procesu włączania, włączania edukacyjnego oraz edukacji włączającej są: uczeń ze specjalnymi potrzebami edukacyjnymi, rodzice/opiekunowie, nauczyciele, inni specjaliści oraz środowisko rówieśnicze i społeczne środowisko lokalne”. Wydaje się więc, że dzięki właściwie przygotowanemu środowisku szkolnemu i zaangażowaniu rówieśników szansa na rzeczywistą inkluzję edukacyjną, a tym samym podniesienie jakości życia dzieci z niepełnosprawnością i ich rodzin może być bardziej realna. Wnioski takie sugerować mogą przedstawione wyniki badań. Prezentowane przez badanych uczniów postawy wobec osób z niepełnosprawnością mogą napawać optymizmem. Dobrym kierunkiem przygotowania włączającego środowiska szkolnego jest wyposażanie młodych ludzi w rzetelną wiedzę na temat potrzeb, możliwości, utrudnień i ograniczeń $\mathrm{w}$ funkcjonowaniu osób $\mathrm{z}$ różnymi rodzajami niepełnosprawności. Na bazie tej wiedzy możliwe będzie przełamywanie stereotypów, pozbywanie się nieuzasadnionych lęków, obaw czy uprzedzeń wobec tej grupy osób, a tym samym burzenie najbardziej dotkliwych z punktu widzenia osób niepełnosprawnych barier utrudniających skuteczną integrację - barier mentalnych. 


\section{LITERATURA}

Czapiński J., 1978, Dyferencjał semantyczny. W: L. Wołoszynowa (red.), Materiały do nauczania psychologii, t. 3: Metody badań psychologicznych. Warszawa, PWN, 257-275.

Frączkiewicz-Wronka A., Zrałek M., Niepełnosprawni w środowisku zamieszkania - projektowanie działań włączających w gminie, 2015, „Studia Biura Analiz Sejmowych", 2(42), 95-121.

Głodkowska J., 2009, W poszukiwaniu modelu edukacji włączającej, „Meritum”, $2,5-8$.

Jakubowska U., 1993, Czynności badawcze w psychologii i pedagogice. Bydgoszcz, Wydawnictwo Uczelniane WSP.

Konwencja ONZ o prawach osób niepełnosprawnych (Dz.U. z dnia 25 października 2012 r., poz. 1169).

Pielecki A., 2013, Zmiany postaw młodzieży wobec osób niepełnosprawnych. Lublin, Wydawnictwo UMCS.

Pilch T., Bauman T., Radźko A., 1995, Zasady badań pedagogicznych. Warszawa, Żak, 43-45.

Profesor Jo Jerg: inkluzja społeczna zaczyna się w naszych głowach, opublikowano: http://www.dw.com/pl/profesor-jo-jerg-inkluzja-spo\%C5\%82eczna-zaczynasi\%C4\%99-w-naszych-g\%C5\%82owach/a-17089914 [dostęp: 13.03.2015].

Soroka-Fedorczuk A., 2007, Osoby niepełnosprawne w opiniach dzieci. Kraków, Oficyna Wdawnicza Impuls.

Uchwała Nr 104 Rady Ministrów z dnia 18 czerwca 2013 r. w sprawie przyjęcia Strategii Rozwoju Kapitału Ludzkiego 2020 (Monitor Polski z 2013 r., Poz. 640). Uchwała Nr 157 Rady Ministrów z dnia 25 września 2012 r. w sprawie przyjęcia Strategii Rozwoju Kraju 2020 (Monitor Polski z 2012 r., Poz. 882).

Zaczyński W.P., 1967, Rozwój metody eksperymentalnej i jej zastosowanie w dydaktyce. Warszawa, Państwowe Wydawnictwo Naukowe.

\section{THE PERCEPTION OF PEOPLE WITH DISABILITIES BY ELEMENTARY SCHOOL STUDENTS. TRANSFORMATION AS A RESULT OF EDUCATIONAL ACTIVITIES}

Abstract: Creating an inclusive and supportive environment, which is an environment that favors the development of people with disabilities, becomes an important challenge of contemporary school. One of the objectives for the realization of this idea is to break stereotypes about people with disabilities and to develop appropriate attitudes towards them. Undertaken 
research was intended to examine attitudes towards people with different disabilities presented by the students of a primary school and to determine their change in the context of educational activities. The results show that properly planned educational programmes familiarizing pupils with various aspects of the functioning of persons with disabilities contribute to a significant change of their attitudes towards them.

Keywords: attitudes towards persons with disability, attitude changes, social inclusion, educational influences 